\title{
Conservation Agriculture for Rice-Based Intensive Cropping by Smallholders in the Eastern Gangetic Plain
}

\author{
Richard W. Bell 1,*(1), Md. Enamul Haque ${ }^{1}$, M. Jahiruddin ${ }^{2}$, Md. Moshiur Rahman ${ }^{3}$, \\ Mahfuza Begum ${ }^{3}$, M. A. Monayem Miah ${ }^{4}$, Md. Ariful Islam ${ }^{5}$, Md. Anwar Hossen ${ }^{6}$, \\ Nazmus Salahin ${ }^{7}$, Taslima Zahan ${ }^{8}$, Mohammad Mobarak Hossain ${ }^{9}$, Md. Khairul Alam 10 (D) and \\ Mir Nurul Hasan Mahmud 11 \\ 1 School of Veterinary and Life Sciences, Murdoch University, South St, Murdoch WA 6150, Australia; \\ e.haque@murdoch.edu.au \\ 2 Department of Soil Science, Bangladesh Agricultural University, Mymensingh 2202, Bangladesh; \\ m_jahiruddin@yahoo.com \\ 3 Department of Agronomy, Bangladesh Agricultural University, Mymensingh 2202, Bangladesh; \\ rahmanag63@gmail.com (M.M.R.); mzap_27@yahoo.co.uk (M.B.) \\ 4 Agricultural Economics Division, Bangladesh Agricultural Research Institute, Gazipur 1701, Bangladesh; \\ monayem09@yahoo.com \\ 5 Pulses Research Centre, Bangladesh Agricultural Research Institute, Ishurdi, Pabna 6620, Bangladesh; \\ arifbau06@gmail.com \\ 6 FMPHT Division, Bangladesh Rice Research Institute, Gazipur 1701, Bangladesh; ahossenbrri@gmail.com \\ 7 Soil Science Division, Bangladesh Agricultural Research Institute, Gazipur 1701, Bangladesh; \\ nsalahin@yahoo.com \\ 8 On-farm Research Division, Bangladesh Agricultural Research Institute, Gazipur 1701, Bangladesh; \\ taslimazahan_tzp@yahoo.com \\ 9 Rice Breeding Platform (Breeding for Favorable Environment), International Rice Research Institute, Metro \\ Manila 1301, The Philippines; shakilmoba@gmail.com \\ 10 Soil Science Division, Bangladesh Agricultural Research Institute, Gazipur 1701, Bangladesh; \\ khairul.krishi@gmail.com \\ 11 Irrigation and Water Division, Bangladesh Rice Research Institute, Gazipur 1701, Bangladesh; \\ hasan11bau@yahoo.com \\ * Correspondence: r.bell@murdoch.edu.au; Tel.: +614-0513-1429
}

Received: 31 October 2018; Accepted: 19 December 2018; Published: 22 December 2018

\begin{abstract}
We review the recent development of Conservation Agriculture (CA) for rice-based smallholder farms in the Eastern Gangetic Plain (EGP) and the underpinning research on agronomy, weed control, soil properties and greenhouse gas emissions being tested to accelerate its adoption in Bangladesh. The studies are based mostly on minimum soil disturbance planting in strip planting (SP) mode, using the Versatile Multi-crop Planter (VMP), powered by a two-wheel tractor (2WT). One-pass SP with the VMP decreased fuel costs for crop establishment by up to $85 \%$ and labour requirements by up to $50 \%$. We developed strip-based non-puddled rice (Oryza sativa) transplanting (NPT) in minimally-disturbed soil and found that rice grain yield increased (by up to $12 \%$ ) in longer-term practice of CA. On farms, $75 \%$ of NPT crops increased gross margin. For non-rice crops, relative yield increases ranged from $28 \%$ for lentil (Lens culinaris) to $6 \%$ for wheat (Triticum aestivum) on farms that adopted CA planting. Equivalent profit increases were from $47 \%$ for lentil to $560 \%$ for mustard (Brassica juncea). Moreover, VMP and CA adopting farms saved 34\% of labour costs and lowered total cost by up to $10 \%$ for production of lentil, mustard, maize (Zea mays) and wheat. Effective weed control was obtained from the use of a range of pre-emergent and post-emergence herbicides and retention of increased crop residue. In summary, a substantial body of research has demonstrated the benefits of CA and mechanized planting for cost savings, yield increases in many
\end{abstract}


cases, increased profit in most cases and substantial labour saving. Improvement in soil quality has been demonstrated in long-term experiments together with reduced greenhouse gas emissions.

Keywords: crop establishment; crop residue retention; fuel use; minimal soil disturbance; planter; non-puddled rice transplanting; strip planting

\section{Introduction}

Agriculture in Bangladesh is facing the ongoing challenge of increasing food security for its growing population (currently 164 million people [1] and expected to reach 205 million by 2050 [2]) and improving overall land use sustainability, while decreasing costs of crop production to increase farm profitability. In a recent review paper on the practice of Conservation Agriculture (CA) (i.e., minimum mechanical soil disturbance, organic soil cover and crop species diversification) by smallholders [3], the authors concluded that it was an approach that could improve soil health, decrease costs of production and increase crop profitability. The present paper outlines the development of a form of CA suited to rice-based cropping in small farms of the Eastern Gangetic Plain (EGP) with particular reference to Bangladesh.

The nation-wide spread of mechanized tillage with two-wheel tractors (2WT), and development over the past decade of a range of minimum soil disturbance planters for $2 \mathrm{WT}$, provide a platform for implementing CA principles that will decrease costs of crop production (less fuel consumption and decreased labour requirements) and improve the fertility of soils in Bangladesh. Evaluation of the Versatile Multi-crop Planter (VMP) [4-6] showed promising results for the establishment and yield of a range of crops in rainfed cropping systems. This novel, lightweight, low-cost planter is now being manufactured in Bangladesh. This paper reviews the systematic work completed on the implications of CA adoption in rice-based systems and on acceleration of adoption of planters for crop establishment on farms. The development of CA in Bangladesh, incorporating the new planters, through on-going research and development demonstrated that crop yields were at least maintained using CA approaches. Effective strategies were developed and evaluated for the engagement of service providers, extension, machinery manufacturers and farmers in the implementation of a form of CA suited to the cropping areas of Bangladesh.

\section{Research Approach and Study Areas}

The research discussed here, conducted during 2008-2018, was focused on target areas to provide a range of soils and cropping systems for the evaluation of CA in Rajshahi, Mymensingh, Rajbari and Thakurgoan districts in Bangladesh (Figure 1). The research reviewed was mostly conducted by a Conservation Agriculture project supported by the Australian Centre for International Agricultural Research (2012-2017). In each of the study areas, cropping systems experiments were established to evaluate the most suitable minimum soil disturbance options and the key limitations to CA and its profitability when applied to rice-based cropping. Experiments were conducted mostly on farms involving farmers' groups and machinery contractors (called local service providers (LSP)), where monsoon (Kharif-2 season) rainfed rice (aman rice), cool-dry season high yield irrigated rice (boro rice) and other non-rice crops in the dry (Rabi) season, e.g., oilseed, pulse or wheat (Triticum aestivum), and pre-monsoon season (Kharif 1) crops, such as aus rice, mung bean (Vigna radiata) or jute (Corchorus capsularis L.), were established, depending on their local suitability. These experiments were supplemented by research and development focused on improvements in minimum soil disturbance machinery, starting with the VMP design, field experiments designed for the diagnosis of agronomic constraints in CA related to weeds and nutrition and studies on improvements in soil fertility associated with minimum soil disturbance, increased retention of crop residues and more diverse crop rotations including pulses and oilseeds. 


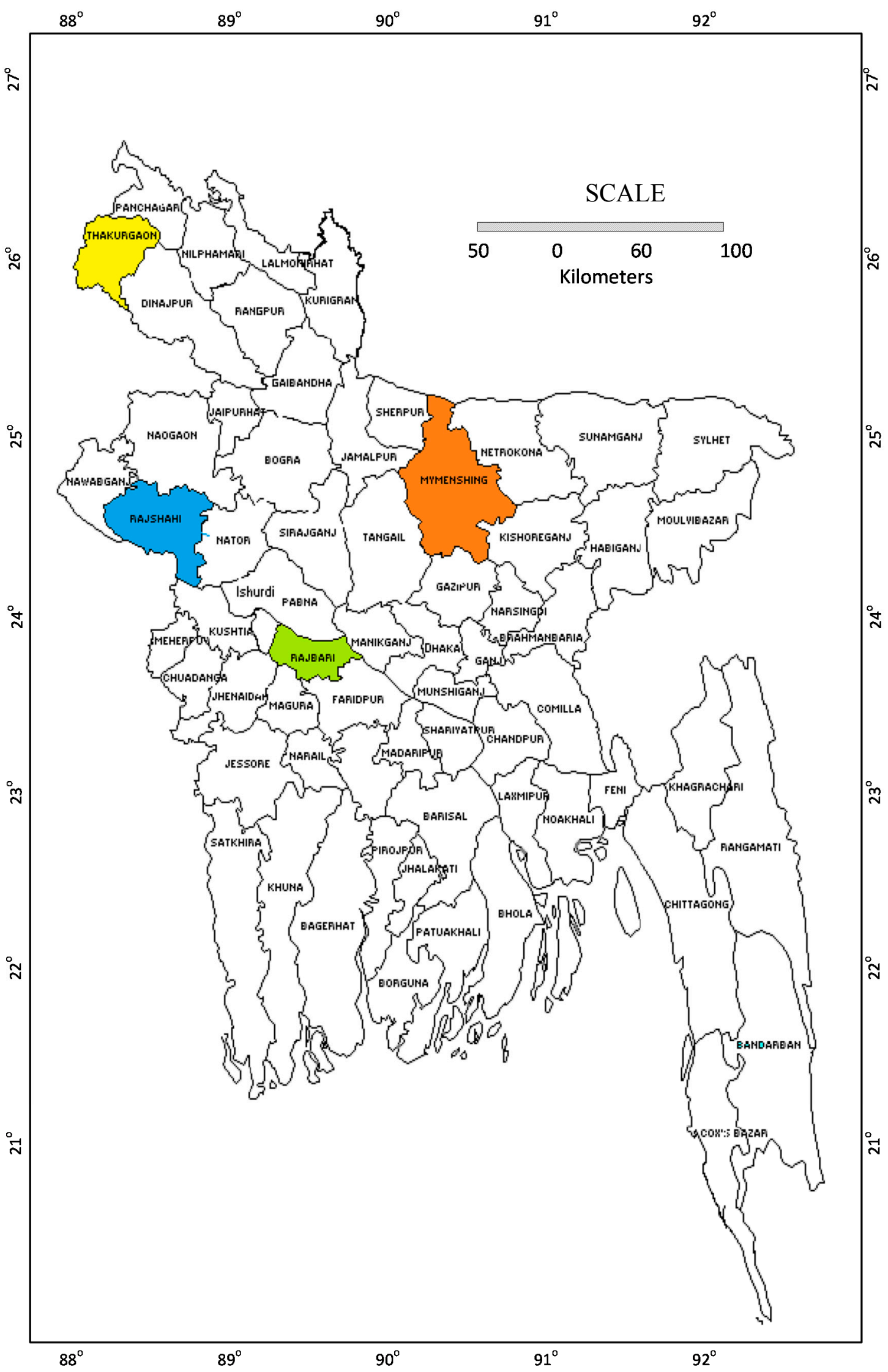

Figure 1. Map of Bangladesh showing the study districts (Thakurgaon, Rajshahi, Mymensingh and Rajbari) marked with different colours. 
To accelerate the development and adoption of CA in Bangladesh, a network of farmers, LSPs, extension officers, Non-government Organizations (NGOs), banks and machinery manufacturers was established. The purpose of this network was to identify constraints to adoption of CA in the machinery and related services value chains, and advocate for research and development on relevant minimum tillage machinery, crop agronomy packages (especially weed control) and soil management technologies for specific cropping systems. This farmer network, known as the Conservation Agriculture Service Providers Association (CASPA), serves as a stakeholder group for dissemination of findings to farmers.

\subsection{Climate of The Studied Areas in EGP}

The average annual rainfall in Mymensingh district is more than $2500 \mathrm{~mm}$, which wis higher than Thakurgaon district $(2218 \mathrm{~mm})$, followed by Rajbari district $(2005 \mathrm{~mm})$ and the lowest is in Rajshahi district $(1581 \mathrm{~mm})$. In all locations where the present studies were done, about $80 \%$ of total rainfall occurs during June to September. The average maximum temperatures are 36, 36, 33 and $32{ }^{\circ} \mathrm{C}$ in Rajshahi, Thakurgaon, Rajbari and Mymensingh, respectively, in April. The lowest average temperatures are $11-12{ }^{\circ} \mathrm{C}$ in January (Figure 2).

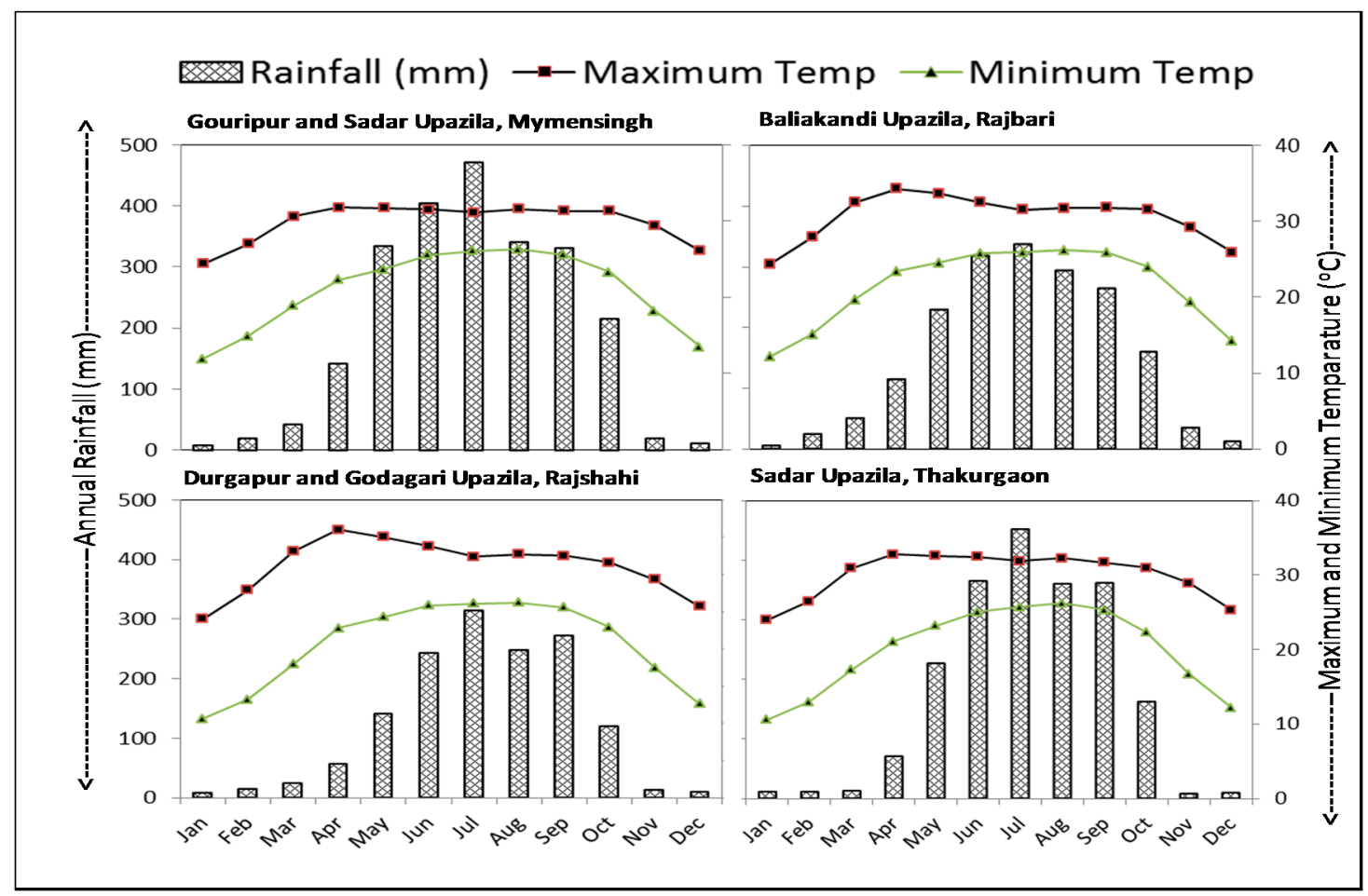

Figure 2. Monthly average rainfall $(\mathrm{mm})$, average maximum and minimum temperature $\left({ }^{\circ} \mathrm{C}\right)$ in study locations (called Upazillas). Data (1980-2012) were collected from nearest weather stations of the Metrological Department of Bangladesh and from [7]. Lines with filled triangles and squares represent the average minimum and maximum monthly temperatures, respectively, and bars represent the monthly average total rainfall.

\subsection{Cropping Pattern}

The study areas in Bangladesh are characterized by diverse crop rotations. Major cropping patterns of the study locations in Thakurgaon are aman rice-potato (Solanum tuberosum)-maize, aman rice-potato-boro rice, aman rice-wheat-fallow and aman rice-boro rice. The cropping patterns in the study area of Rajshahi are aman rice-lentil-aus rice, aman rice-mustard-boro rice, aman rice-wheat-mung bean and aman rice-wheat-fallow. In the study location of Mymensingh, the 
cropping patterns are aman rice-wheat-mung bean and aman rice-fallow-boro rice. In Rajbari, major cropping patterns are aman rice-onion (Allium cepa)-jute, aman rice-wheat-jute and aman rice-garlic (Allium sativum)-jute. Planting and harvesting dates of the crops in the study areas are given in Figure 3.

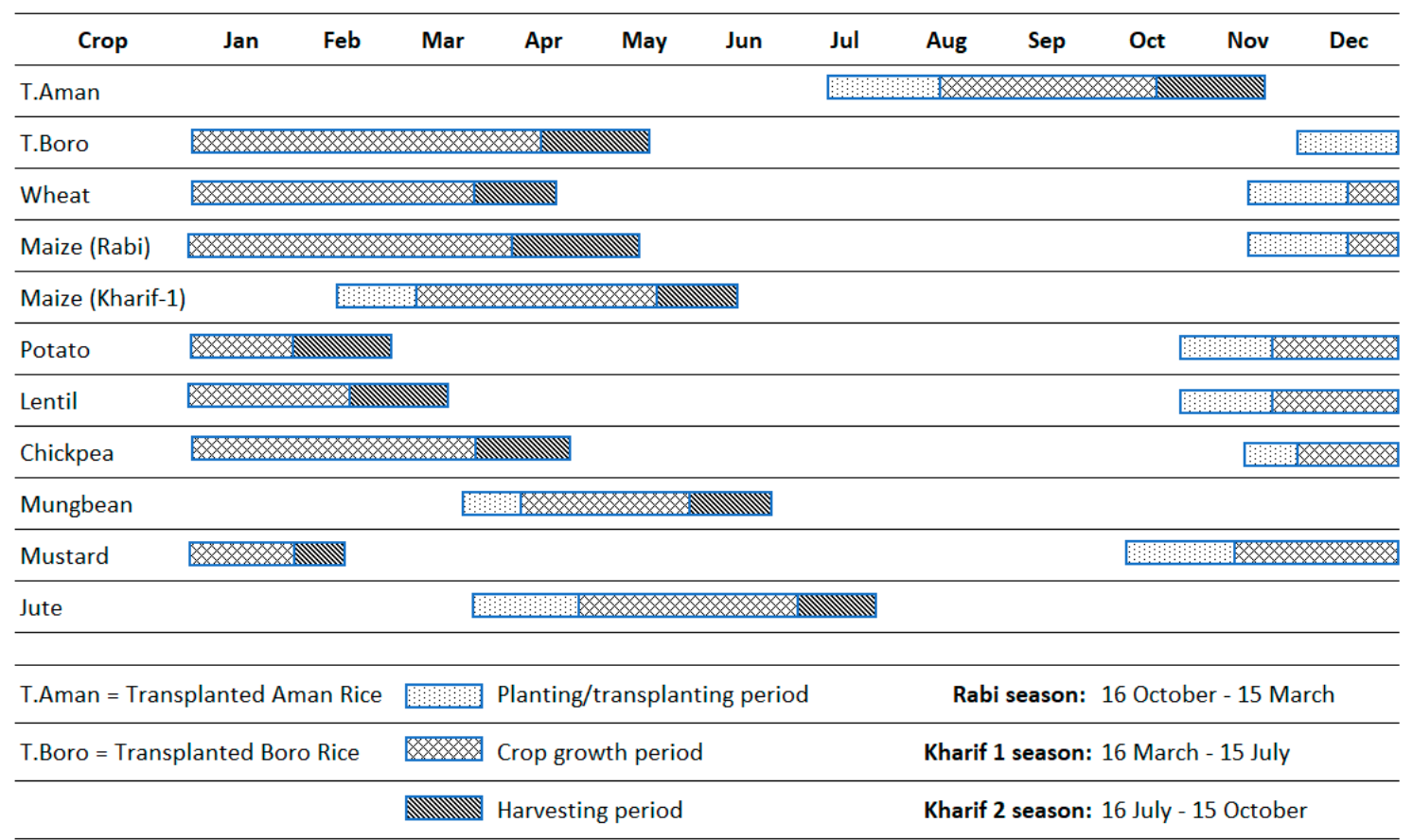

Figure 3. Major crops in the studied areas showing planting dates and harvest dates for the major crops referred to in the present study.

\subsection{Rice Cultivation in Conservation Agriculture}

Soil puddling for transplanting rice seedlings is not a CA practice. For the adoption of CA in rice-based cropping systems, a method of rice establishment involving minimum soil disturbance is needed. We developed non-puddled transplanting (NPT) for establishment of rice seedlings in minimally-disturbed soil [8]. The NPT method involves strip tillage in dry soil using the VMP, followed by saturation of the soil for $18-24 \mathrm{~h}$ to soften the soil in the strip. Seedlings are then transplanted into the non-puddled strip. Non-puddled transplanting can be applied into standing crop residues, and usually involves application of a non-selective herbicide such as glyphosate to control weeds before strip preparation. Grain yield increased by up to $12 \%$ with the longer-term practice of NPT rice together with SP of other crops in the rotation, while no yield loss was reported relative to the conventional puddled transplanting $(\mathrm{CP})$ of rice. However, land preparation cost was reduced significantly by NPT rice establishment.

In the on-farm comparisons of NPT in minimally-disturbed soil, few farmers obtained lower yields than in the rotary-tilled CP fields. In the monsoon season, 53 out of 66 farmers who practiced NPT reported higher net returns than in full tilled CP while 49 out of 66 farmers reported higher rice grain yield (Figure 4). In boro season of 2013, 2014 and 2015, the net return was higher in 78 of 84 cases in NPT rice while 62 of 84 had the same or higher grain yield than CP (Figure 4). 
[A] Grain yield of aman rice $\left(\mathrm{t} \mathrm{ha}^{-1}\right)$

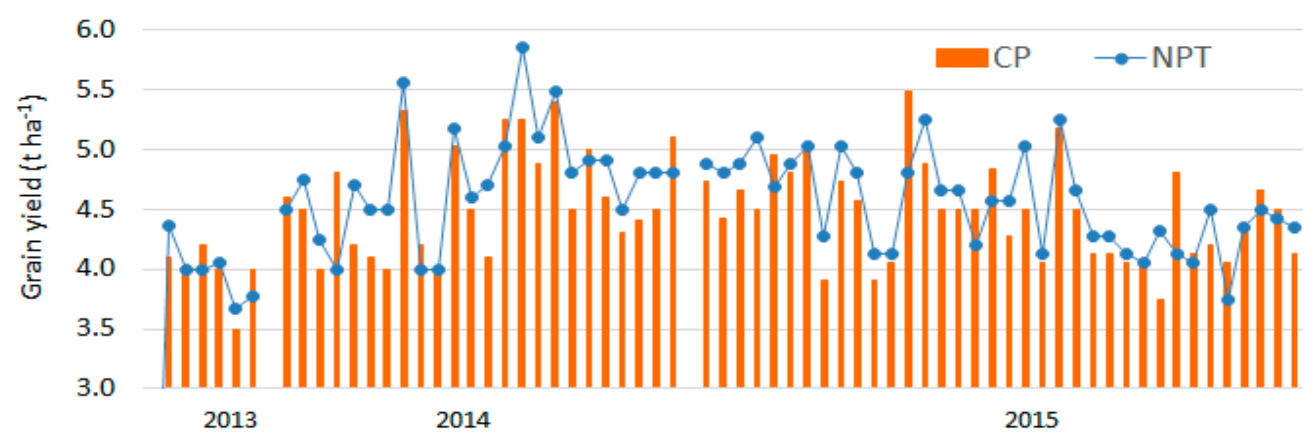

[B] Net return of aman rice (US\$ ha-1)

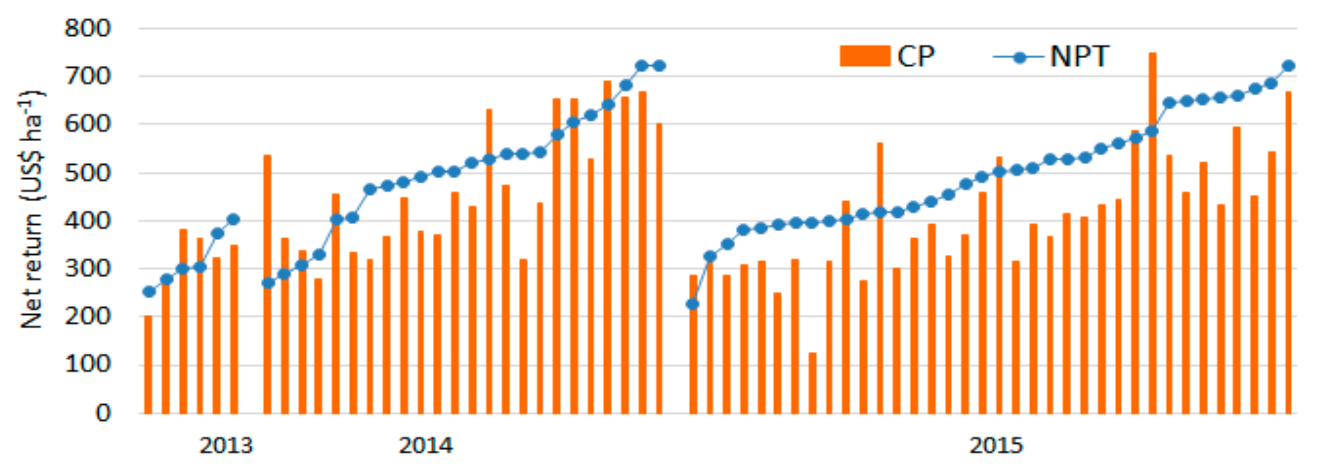

[C] Grain yield of boro rice $\left(\mathrm{t} \mathrm{ha}^{-1}\right)$

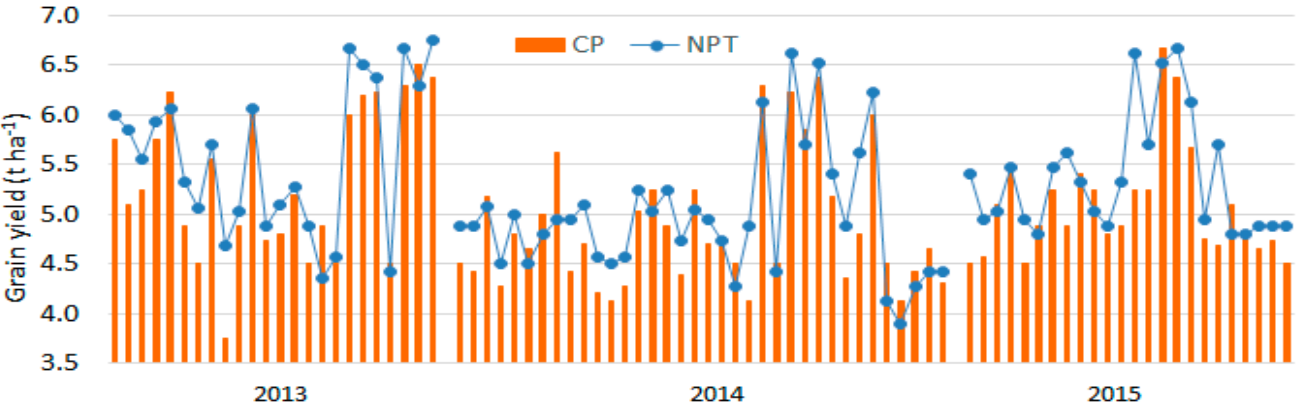

[D] Net return of boro rice (US\$ ha-1)

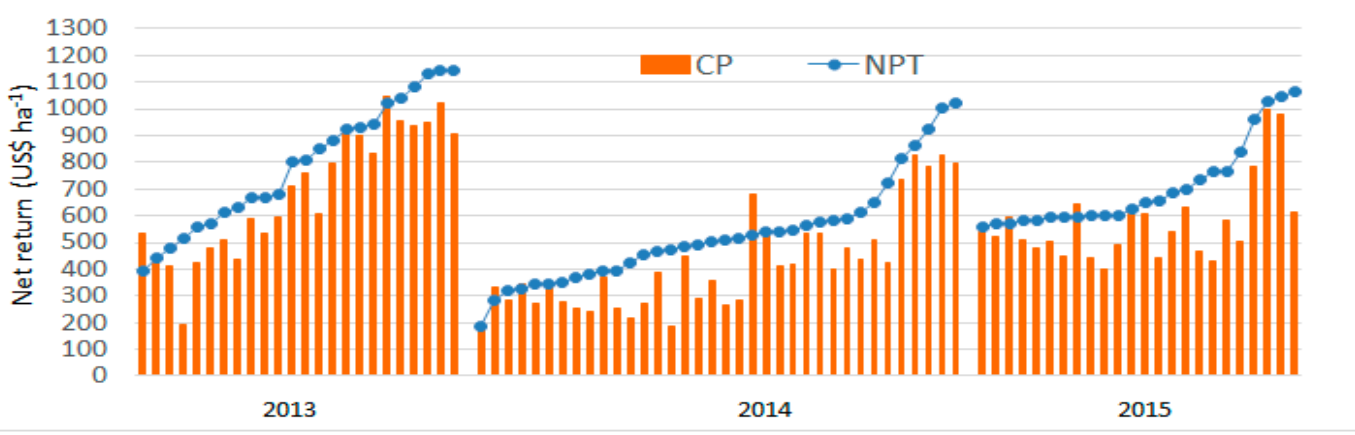

Figure 4. Individual farmer's wet season (aman) (A) and irrigated rice (called boro) (C) grain yield $\left(\mathrm{t} \mathrm{ha} \mathrm{a}^{-1}\right)$, and net return of aman (B) and boro rice (D) comparison between paired crops established by non-puddled transplanting of rice seedlings (NPT) (blue line with round bullets) relative to conventionally-puddled transplanting of rice seedling (CP) (orange coloured bars) during 2013, 2014 and 2015. The values for paired crops are arranged in order of the NPT net return for each year. Net return values are based on the average market price for rice in the three years. Rice crops were generally sown on different fields in each year. 


\subsection{Designing Minimum Tillage Planters for Improved Operation and Effectiveness}

There are few planters available for CA planting of crops in the EGP using the 2WT, and none were considered to have sufficient flexibility or versatility to develop a profitable LSP business operation for crop establishment in the diversified cropping systems of the EGP [9]. The VMP was designed and developed as a seeder for smallholder farms and operation by a 12-16 horsepower 2WT making it suitable for the EGP [4]. It can deliver seed and fertilizer into the soil behind the tyres and the rates of application can be adjusted. Seeding depth and row spacing can also be adjusted while planting by strip planting (e.g., SP), zero tillage, single pass shallow tillage, shallow beds and conventional tillage (CT). The shaft and brackets of the VMP were designed (Figure 5) for flexibility for multi-crop planting with basal fertilizer banding in line, and capacity for rapid adjustment of seed and fertilizer rate, seed depth and row spacing on crop-by-crop and field-by-field bases.

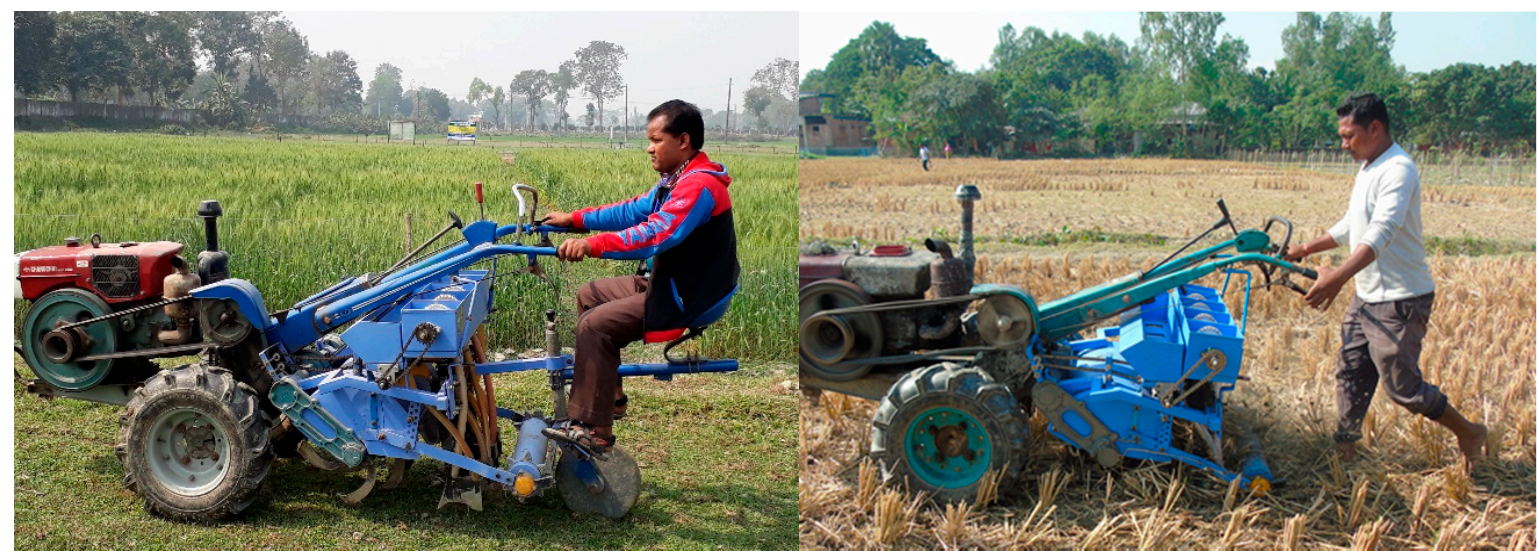

Figure 5. VMP, attached to a 2WT: in transportation mode (left); and field operation mode (right).

A related planter that only has strip planting capability is the Versatile Strip Seed Drill (VSSD) [9], also developed in Bangladesh. The VMP [4] and VSSD [9] have now been tested extensively in Bangladesh. Both have the capacity for use as a 2WT-based CA planter in cropping systems used by smallholder farmers more widely in Asia, Africa and other regions.

The field capacity of VMP was $0.07 \mathrm{ha}^{-1}$ for SP which was $34 \%$ higher than for CT due to the reduced number of operations [4,5]. Land preparation cost by VMP was decreased by up to $75 \%$ for SP compared to CT. The VMP was capable of sowing many crops from small jute seed ( $2 \mathrm{~g}^{-1000}$ seeds) up to maize (160 $\mathrm{g}^{-1000}$ seed) (Table 1). The latest VMP (Model 13, Figure 5) weighs $152 \mathrm{~kg}$ excluding the driver's seat and rear wheel for road transportation and ex-factory price is US $\$ 1000$.

Table 1. Seed rate, row spacing and seeding methods for strip planting of crops using the VMP.

\begin{tabular}{|c|c|c|c|}
\hline Name of The Crops & Seed Rate (kg ha $\left.{ }^{-1}\right)$ & $\begin{array}{l}\text { Adjustable Row Spacing } \\
(\mathrm{cm})\end{array}$ & $\begin{array}{c}\text { Distance between Seeds } \\
(\mathrm{cm})\end{array}$ \\
\hline Direct seeded rice & $16-18$ & 20 & 20 \\
\hline Wheat & $110-120$ & 20 & Continuous \\
\hline Maize (hybrid) & 83,330 plant ha $^{-1}$ & $58-60$ & 20 \\
\hline Mung bean & $28-30$ & 30 & $3-4$ \\
\hline Lentil & $30-34$ & 20 & Continuous \\
\hline Sesame (Sesamum Indicum L.) & $4-5$ & 20 & Continuous \\
\hline Mustard & $3.5-4.5$ & 20 & Continuous \\
\hline Chickpea (Cicer arietinum L.) & $40-45$ & 30 & $3-4$ \\
\hline Jute & $3-4$ & 20 & Continuous \\
\hline
\end{tabular}

Fuel consumption while strip planting by VMP decreased from 33.1 to $5.83 \mathrm{~L} \mathrm{ha}^{-1}$ ) (Table 2). The maximum cost (US $\$ 41.47 \mathrm{ha}^{-1}$ ) of land preparation and seeding was incurred in the case of CT system and the lowest (US\$10.27 ha ${ }^{-1}$ ) for strip planting. 
Table 2. Effect of crop establishment mode by the VMP on fuel consumption, field capacity, labour requirement and cost of land preparation and seeding for lentil, chickpea, mung bean and black gram (Vigna mungo) in clay soil on the High Barind Tract, Rajshahi, Bangladesh, 2010-11. Summarized from [5].

\begin{tabular}{|c|c|c|c|c|}
\hline Tillage Type & $\begin{array}{l}\text { Field Capacity } \\
\quad\left(\mathrm{ha} \mathrm{hr}^{-1}\right)\end{array}$ & $\begin{array}{l}\text { Fuel Consumption } \\
\qquad\left(1 \mathrm{ha}^{-1}\right)\end{array}$ & $\begin{array}{c}\text { Labour } \\
\text { Requirement, } \\
\text { (person-hr ha }{ }^{-1} \text { ) }\end{array}$ & $\begin{array}{c}\text { Cost of Land } \\
\text { Preparation, } \\
\text { Fertilizing and } \\
\text { Seeding }^{\text {a }}\left(\mathrm{US} \$ \mathrm{ha}^{-1}\right)\end{array}$ \\
\hline Conventional (4 tillage passes) (CT) & $0.03 \mathrm{c}$ & $33.1 \mathrm{a}$ & $48.1 \mathrm{a}$ & $41.5 \mathrm{a}$ \\
\hline Shallow depth full tillage (single pass) & $0.07 \mathrm{a}$ & 20.6 c (38) & 15.4 c (68) & $19.8 \mathrm{~d}(52)$ \\
\hline Strip planting (single pass) & $0.07 \mathrm{a}$ & 5.83 e (82) & 15.3 c (68) & $10.3 \mathrm{~d}(75)$ \\
\hline Zero tillage (single pass) & $0.06 \mathrm{ab}$ & $16.6 \mathrm{~d}(50)$ & 17.3 c (64) & 18.1 c (23) \\
\hline
\end{tabular}

Values in parentheses indicate the percent saving over CT. Values in a column, followed by a common letter are not significantly different at $p<0.01$ by Duncan's Multiple Range Test. ${ }^{a}$ Considering variable costs for labour (land preparation @Taka 30 and seeding @Taka 20 ha $^{-1}$ ) and diesel fuel (@Taka $45 \mathrm{~L}^{-1}$ ); 1 US\$ = 68 Taka in 2010-11).

\subsection{Weed Management-Including the Role of Residue}

Herbicidal weed control is now a common practice for conventional full tillage-based agriculture [10]. Experiments were conducted to assess the effectiveness of herbicide and/or crop residue use to control weeds under CA in a range of crops. The benefit-cost ratio (BCR) with SP and NPT followed by the application of pre-emergence and post emergence herbicides was much greater than for CT and CP and hand weeding [11,12]. Retention of 50\% residue increased the grain yield by $4 \%$ and BCR by $9 \%$. The weed seed bank study revealed that, after the two-year field experiment, the practice of $\mathrm{CP}$ for rice and $\mathrm{CT}$ for non-rice crops enriched the seedbank weed numbers by $13 \%$ while SP and NPT reduced seedbank numbers by $17 \%$. Residue retention diminished the weed seedbank numbers by $11 \%$. Even though residue retention levels did not exceed $50 \%$, the increased residue helped to suppress weeds and is a useful component of the weed control strategy of CA practice [13]. After 3-5 years of continuous CA practice, the weed seedbank was reduced by $30-35 \%$ compared to the current conventional practice [13]. Hence, in the medium to long term, there is likely to be less difficulty suppressing weeds in the CA fields.

From a number of experiments with both rice and wheat as well as mustard, the best weed control was obtained from sequentially applied pre-emergence and post-emergence herbicides. Herbicides applied in NPT aman rice had no residual effects on the succeeding crops of wheat, lentil or sunflower (Helianthus annuus) [11]. Similarly, no toxicity was detected in mung bean grown after various herbicides were used to treat weeds in wheat [14]. Phytotoxic effects of some herbicides were recorded in rice and wheat, depending on cultivar and rate of herbicide application. While almost all rice and wheat cultivars tested were tolerant to herbicides at the label rate, there were some exceptions. The implications of these findings are that screening of cultivars, especially new cultivar releases, needs to be institutionalized within national breeding programmes, since the use of herbicides for weed control (for conventional and CA practice) is quickly becoming the norm rather than an exception in farmers' fields in the EGP [10].

Field experiment showed that application of herbicides has significantly reduced weed infestation in wheat and rice fields under SP and provided up to $227 \%$ and $28 \%$ higher grain yield of SP-based wheat and NPT-based rice, respectively, compared to non-weeded plot [11,12].

For aman rice established by NPT, the best weed control was obtained from sequentially applied pyrazosulfuron-ethyl, orthosulfamuron and butachlor + propanil [14]. It provided similar or better grain and straw yield as weed-free control and gave the highest net benefit among all treatments during successive years. Selection of herbicides with different modes of action is an essential tool to minimize the risk of herbicide resistance developing in weeds. From several papers [11-16], it can be concluded that rotational use at the recommended dose of the effective herbicides in a rice-wheat-mung bean pattern could be effective to control weeds in the CA system as the herbicides applied to rice and wheat had no residual effect on the succeeding crops. Moreover, almost all rice and wheat varieties were tolerant to herbicides at the recommended rate on the product label. 


\subsection{Benefit of CA for Soil Fertility}

After 2.5 years in both legume- and cereal-dominated rotations, the soil organic carbon (SOC) concentration and SOC content at 0 to $7.5 \mathrm{~cm}$ soil depth were greater in SP + NPT than CT + CP [17]. By contrast, the $\mathrm{SOC}$ concentration and content at 7.5 to $15 \mathrm{~cm}$ remained unchanged between $\mathrm{CT}+\mathrm{CP}$ and SP + NPT. Soil organic $\mathrm{C}$ losses through the emission of $\mathrm{CO}_{2}$ were greater in $\mathrm{CT}+\mathrm{CP}$ than $\mathrm{SP}+$ NPT. High residue retention increased SOC concentration, SOC content, and $\mathrm{CO}_{2}$ emission from soil. In the cereal-dominated rotation, $\mathrm{SP}+\mathrm{NPT}$ sequestered $0.20-0.44 \mathrm{Mg} \mathrm{C} \mathrm{ha}^{-1}$ annually, while CT + CP caused $0.41-0.66 \mathrm{MgC} \mathrm{ha}{ }^{-1}$ loss at $0-15 \mathrm{~cm}$ soil depth. In contrast to the legume-dominated rotation, neither $\mathrm{CT}+\mathrm{CP}$ nor SP + NPT sequestered SOC but SP + NPT reduced the loss by $0.40 \mathrm{Mg} \mathrm{C} \mathrm{ha-1}$ annually compared to $\mathrm{CT}+\mathrm{CP}$. Based on the $\mathrm{C}$ balance, it is estimated that annual organic matter inputs of $4 \mathrm{MgC} \mathrm{ha}{ }^{-1}$ under SP $+\mathrm{NPT}$ and $6 \mathrm{MgC} \mathrm{ha}^{-1}$ under $\mathrm{CT}+\mathrm{CP}$ condition in the legume-dominated system, and $1 \mathrm{MgC} \mathrm{ha}{ }^{-1}$ under $\mathrm{SP}+\mathrm{NPT}$ and $8 \mathrm{Mg} \mathrm{C}^{-1}$ under $\mathrm{CT}+\mathrm{CP}$ condition in the cereal-dominated system, would be required to maintain SOC at the antecedent level. Application of SP + NPT and retention of higher levels of crop residue (HR) have the potential for increasing C sequestration and $\mathrm{N}$ accumulation, while reducing $\mathrm{N}$ losses. Such improvements in soil properties and thereby in crop growth and yields, were obtained after 2-3 years of CA practice in rice-based systems of Bangladesh.

After five years practicing CA (using crop establishment by SP for non-rice + NPT for rice), the increase in SOC was 65-68\% at the long-term experiments at Durgapur and Godagari of Rajshahi district [18]. The increase in SOC was equivalent to an additional 3.8-4.2 $\mathrm{t}$ of $\mathrm{C} \mathrm{ha}^{-1}$ in the soils after five years under CA (SP for non-rice + NPT for rice with increased residue retention) (see Table 3 for the results at the Godagari, Rajshahi site). Soil N storage also increased with the CA practices, which also decreased soil bulk density and increased soil porosity [19].

Table 3. Selected physical and chemical characteristics of the $0-10 \mathrm{~cm}$ soil layer of the studied area at Godagari, Rajshahi after five years of Conservation Agriculture practices (SP + NPT, increased residue retention, and crop rotation). From $[18,19]$.

\begin{tabular}{|c|c|c|c|c|c|c|}
\hline \multirow[b]{2}{*}{ Treatments } & \multicolumn{6}{|c|}{ Characteristics } \\
\hline & $\begin{array}{l}\text { Bulk density } \\
\qquad\left(\mathrm{g} \mathrm{cm}^{-3}\right)\end{array}$ & $\begin{array}{c}\text { Porosity } \\
\text { (\%) }\end{array}$ & $\mathrm{pH}\left(\mathrm{H}_{2} \mathrm{O}\right)$ & $\begin{array}{c}\text { Total N } \\
\left(\mathrm{g} \mathrm{kg}^{-1}\right)\end{array}$ & $\begin{array}{c}\text { Total } \\
\text { organic C (t } \\
\left.\mathrm{ha}^{-1}\right)\end{array}$ & $\begin{array}{l}\text { Microbial } \\
\text { Biomass C } \\
\left(\mathrm{mg} \mathrm{kg}^{-1}\right)\end{array}$ \\
\hline $\mathrm{CT}+\mathrm{CP}$ with $\mathrm{LR}$ & $1.53 \mathrm{a}$ & $40.5 \mathrm{~d}$ & 6.10 & $0.49 c$ & $6.43 \mathrm{~d}$ & $93 \mathrm{~b}$ \\
\hline $\mathrm{CT}+\mathrm{CP}$ with $\mathrm{HR}$ & $1.46 \mathrm{~b}$ & $43.1 \mathrm{~b}$ & 6.40 & $0.58 \mathrm{~b}$ & $7.83 \mathrm{c}$ & $136 \mathrm{a}$ \\
\hline SP + NPT with LR & $1.50 \mathrm{ab}$ & $41.9 \mathrm{c}$ & 6.40 & $0.59 \mathrm{~b}$ & $9.00 \mathrm{~b}$ & $84 \mathrm{~b}$ \\
\hline SP + NPT with HR & $1.40 \mathrm{c}$ & $45.1 \mathrm{a}$ & 6.70 & $0.76 \mathrm{a}$ & $10.22 \mathrm{a}$ & $142 \mathrm{a}$ \\
\hline
\end{tabular}

Note: CT, Conventional full tillage for non-rice crops; CP, Conventional puddled soil for rice crops; SP, Strip planted for non-rice crops; NPT, Non-puddled transplanting of seedlings for rice crops; LR, Low residue (farmers' practice) level; HR, Increased residue level; Ns, Non-significant. Values in a column, followed by a common letter are not significantly different at $p<0.05$ by the least significant difference Test.

The research at Rajbari on a light textured soil concluded that the minimum soil disturbance practices $((\mathrm{SP}+\mathrm{NPT})$ and zero tillage $(\mathrm{ZT}+\mathrm{NPT}))$ increased SOC, total N $(\mathrm{TN})$ and extractable sulphur (S) and zinc ( $\mathrm{Zn})$ contents in the uppermost $0-5 \mathrm{~cm}$ soil layer [20]. The $0-5 \mathrm{~cm}$ soil depth was enriched with SOC and TN content by $24 \%$ and $23 \%, 23 \%$ and $18 \%$, and $11 \%$ and $9 \%$ under ZT + NPT, SP + NPT and $\mathrm{CT}+\mathrm{CP}$ practices, respectively, in contrast with the initial values. By contrast, the accumulation of extractable phosphorus $(\mathrm{P}), \mathrm{S}$ and $\mathrm{Zn}$ followed the sequence $\mathrm{ZT}+\mathrm{NPT}>\mathrm{SP}+\mathrm{NPT}>\mathrm{CT}+\mathrm{CP}$ practice. The increased residue retention significantly increased SOC, TN, extractable P, potassium (K), S, Zn and boron (B) contents. Crop establishment and crop residue retention had significant influence on the soil penetration resistance and soil water content (SWC), but not soil bulk density. The SP + NPT and HR conserved more SWC and decreased penetration resistance values compared to CT + CP practices with LR. The SP + NPT practices increased grain yield of rice and lentil and yield of jute fibre, but 
not the grain yield of wheat [21]. Higher crop residue retention increased the yield of jute fibre, rice and wheat.

Based on average gross margin and BCR, SP + NTP together with increased (50\% vs. $20 \%$ cereal crop residue retention) was more profitable for aman rice, jute and wheat production than other crop establishment and residue retention combinations [20]. The study suggests that SP + NPT coupled with increased crop residue retention is a suitable crop establishment and residue management system for rice-jute-based cropping to maintain soil fertility, farm profitability and productivity of crops.

Up to Crop 7 in a rice-wheat-mung bean rotation, there was no indication that SP + NPT or increased crop residue retention altered the $\mathrm{N}$ fertilizer requirements for maximum yield of rice or wheat [22]. Research results showed that both $\mathrm{NH}_{4}-\mathrm{N}$ and $\mathrm{NO}_{3}-\mathrm{N}$ levels in standing water were 20-30\% higher after CP rice establishment compared to NPT rice systems. This result indicates that more $\mathrm{N}$ loss might occur for the case of $\mathrm{CP}$ compared to NPT.

Soil carbon sequestration was higher in SP + NPT together with increased crop residue retention than those of other treatment combinations. The carbon sequestration was positive and ranged from 35.2 to $288 \mathrm{~kg} \mathrm{C} \mathrm{t}^{-1}$ of rice production. The NPT of rice can potentially avoid $29 \%$ of the $\mathrm{CO}_{2}$-eq emissions occurring with $\mathrm{CP}$ of soil under the current low level of crop residue retention [23]. For the aman rice crop, NPT of rice with current crop residue retention decreased life cycle greenhouse gas emission by $22 \%$ relative the $\mathrm{CP}$ with the low current crop residue retention [18]. While increased crop residue retention with NPT of rice was not as effective in saving greenhouse gas emissions (it increased $\mathrm{CH}_{4}$ emissions) as the current low crop residue retention, it produced greater rice yield and contributed to greater SOC, decreased bulk density and increased porosity of soil.

\subsection{Conservation Agriculture as a Rice-Based System}

The feasibility of CA as a rice-based system should be assessed after several years, since CA is a cropping system change that needs time to fully express the changes in soils and weeds that occur. In the Bangladeshi studies, the feasibility and benefits of CA are best illustrated by six long-term experiments, some of which have reached 21 consecutive crops [24]. All of them include at least one aman rice crop per year. Other crops include wheat, mustard, lentil, chickpea, jute, mung bean and boro rice. The sites are located in different agro-ecosystem zones, with varied climate, soil type, land type (elevation) and hydrology (Figures 1 and 2). Overall, there are consistent findings that NPT rice in these experiments yielded the same as in CP soil or more. This means that, by using NPT, CA can be practiced as a system all-year round in the rice-based cropping patterns of Bangladesh and probably more widely in the EGP.

Transplanting rice seedlings into non-puddled soils with minimum soil disturbance is an opportunity to expand the adoption of the CA in rice-based cropping systems [8]. Manual transplanting of rice seedlings for both puddled and non-puddled conditions is time consuming, labour intensive and costly. To introduce mechanized rice seedling transplanting into non-puddled soils, two approaches were studied, both using transplanters already used for puddled soils. In the first approach, strips were prepared by VMP in dry or moist (i.e., not-saturated) soil. Then, the field was flooded for 18-24 $\mathrm{h}$ based on soil condition so that the soil in the strips became soften, followed by transplanting of rice seedlings into the strips by a walk-behind type of rice transplanter [25]. Secondly, an experimental rice transplanter was developed [25] for transplanting of rice seedlings into wet non-puddled soils in a single pass operation, incorporating a narrow strip (3-4 $\mathrm{cm}$ width) making mechanism. Detailed performance results and the construction design of the rice transplanter, modified for making tilled strips in non-puddled soil, is described in [26]. From evaluations of the rice transplanter on a research farm and on farmers' fields, mechanised NPT saved 50-70\% time and 46-60\% fuel for transplanting of rice seedlings relative to the CP. However, the use of non-puddled rice transplanter reduced fuel consumption for mechanical transplanting by $10-18 \%$. Overall, in NPT, the non-puddled transplanter covered more area per day than when operated in CP. Collectively, rice seedling transplanting in NPT mode gave significantly higher rice grain yield than CP $[25,26]$. 
In summary, the CA practice increased crop production, largely due to the increased yield of non-rice crops, and profit, by decreasing cost of crop production (reduced labour, machinery hire and fuel). While most of the long-term experiments were conducted on farmers' fields, there are still few farmer-managed fields where continuous CA practice has occurred for significant lengths of time. Targeting the early adopters of CA to assess the benefits accrued by farmers in the medium to long term is therefore a priority for future research.

\subsection{Water Balance}

Water savings are the key benefit for CA, particularly in rainfed cropping in semi-arid and arid environments. Water savings are achieved by minimum soil disturbance that slows the loss of soil water by evaporation. In addition, soil cover by standing or prostrate crop residue slows the rate of soil water evaporation. The cooler temperatures under retained residue also contribute to slower evaporation loss of soil water. To date, only limited research has been done on the water savings under CA in the EGP, and most of this has been under irrigated crops where less irrigation water has been reported to be adequate for wheat and rice.

The long-term experiments with CA for monsoon rice-wheat-mung bean and monsoon rice-lentil-boro rice crop rotations on silty clay loam soils at Rajshahi, Bangladesh were used to estimate irrigated water use [27]. Over three years, SP + NPT saved 11-33\% of water compared to CT + CP. Water productivity of wheat was higher in SP compared to CT in three years. In 2015, water productivity of wheat was 2.06 and $1.25 \mathrm{~g}_{\text {grain }} \mathrm{kg}^{-1}$ water for SP and CT, respectively. Similarly, water

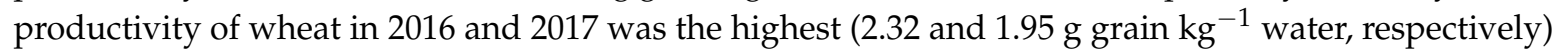
in SP [27].

\subsection{Local Service Providers}

Local service providers are widely spread in rural Bangladesh providing a diverse range of mechanization services (ploughing, transportation, pumping, threshing, and shelling). The LSP are expected to have a key role in making CA accessible to farmers, in driving the development of the technology including improvements in the VMP and other planters.

During 2012-2017, up to 50 VMPs that were operating commercially by LSP were monitored closely to collect business performance data. On average, each VMP covered 6.5 ha during 2012-2013 and increased to 18.9 ha in 2016-2017. During this period, the number of farmers served by each LSP increased from 31 to 75 [28]. In 2017, 18 LSP were selected from Rajshahi, Thakurgaon, Mymensingh and Rajbari districts for a study of their business model. The study revealed that LSPs effectively utilized the VMP and 2WT for 4-6 months. They received US $\$ 1745$ per year as net income. The average payback period for the VMP purchase was 0.98 years. The annual break-even use of the VMP was 7.8 ha [28].

To select new LSP for VMP sales, Hoque Corporation (HC) targeted clients in project working hubs who were existing service providers that already owned a 2WT since the tractor is essential to operate the VMP. These LSPs had the financial means to buy a VMP; they were well known in their community for selling tillage services; they were business-minded, risk takers who were open to try new technologies compared to traditional farmers; they had mechanical skill and required minimal training on VMP operation and maintenance; they already were a trusted source of advice to farmers in their locality; and they had established linkages with other key stakeholders, namely, extension agencies, CASPA and local administration of their community. A feature of the current promotion strategy for the VMP is to engage groups of 25-40 neighbourhood farmers who agree to purchase planting services of the new LSP. The assurance of planting business is a strong incentive for the new LSP to commit to a bank loan for VMP purchase. 


\subsection{Commercialization Models Tested}

Having established that CA in Bangladesh is feasible and a profitable venture for smallholder farmers, and that the LSP business is profitable for planting by VMP, the next step was to develop a commercialisation approach to make VMPs available in the market at an affordable price. The commercialisation approach being pursued involves the creation of both supply and demand for CA services including the VMP for planting. Over emphasis on either demand creation or on supply is unlikely to trigger a breakthrough in commercialisation of the VMP or related planters. Several manufacturers were reluctant to invest without evidence of demand. On the other hand, where manufacturers supplied only to bulk orders from project funds there was little feedback from users on how to improve design and performance of planters and often poor-quality planters were supplied. Low quality planters hampered initial efforts to develop farmer confidence in planters and create demand. To create demand, the Conservation Agriculture Project trained over 300 LSPs, technicians from the National Agricultural Research and Extension System, NGOs, the private sector and local mechanics in the manufacturing factory or repair workshops. Over 6600 farmers hired/used VMP/VSSD to sow lentil, mustard, mung bean, sesame, jute, wheat, maize, rice, chickpea, etc. on more than 1500 ha. This illustrates the level of demand already created in the six study areas (Figure 1).

Of the five manufacturers provided with designs for the VMP, only Hoque Corporation has taken the initiative to develop the market for VMPs by setting up distribution and sales networks and developing a supply chain to manufacture or import component parts, maintain quality control of component parts and the VMP, seek orders and deliver on time, continuously upgrade designs for user satisfaction and provide after sales service. An important component of the commercialisation model developed with Hoque Corporation is the training of LSPs. New LSPs are provided with repeated training sessions in the operation of the VMP and related services such as crop production, agronomy and weed during the first 1-2 years after purchasing the VMP. Experienced operators are engaged to provide training and to mentor the new LSPs.

\subsection{Improved Adoption of CA Led by A Service Provider Network}

Elsewhere in the world where CA has been widely adopted by farmers, it was supported by partnerships between farmer groups and other key stakeholders: manufacturers of machinery, extension officers, researchers, and agricultural input suppliers (e.g. herbicide suppliers) [29]. In the EGP and Bangladesh in particular, LSPs are an additional stakeholder that need to be involved in the partnership, since LSPs are widespread and already provide ploughing, pumping and threshing services on a custom-hire basis to most smallholder farms. To create partnerships between LSPs and farmers, we identified 224 farmers' groups working in nine districts (with a membership of 9800 farm families) and established the Conservation Agriculture Service Providers Association (CASPA). In collaboration with the CASPA and Department of Agricultural Extension (DAE), the Conservation Agriculture project: established 3414 farmers' participatory demonstrations (farmers contributed most of the inputs, and the Conservation Agriculture project provided only the critical inputs) on minimum tillage, residue retention, crop rotation, weed management, NPT rice establishment, etc.; trained 9800 farm families on CA and integrated weed management practices and safe use of herbicides; and organized 116 field days, focus group discussion sessions and promotional meetings that reached 10,894 farmers most of whom practising CA or one of its principles: crop residue retention, crop rotation (e.g., lentil adoption in Rajshahi and mustard between two rice crops at Mymensingh), SP systems for non-rice crops and NPT for rice establishment.

From initial on-farm studies, we estimated that farmers who adopted VMP and CA technologies have gained up to $38 \%, 8 \%$ and $6 \%$ more grain yield of lentil, mung bean and wheat, respectively, over conventional practice [30]. The CA adopters obtained higher net return of US\$366, US\$93 and US\$195 ha ${ }^{-1}$ for lentil, mung bean, and wheat, respectively, over conventional methods. It was estimated the profit from NPT rice compared to CP systems was US\$105-127 ha ${ }^{-1}$ [31]. 
Farmers that used CA in a three-crop rotation within a year could achieve $29 \%, 54 \%$, and $14 \%$ greater net profit (additional income of US $\$ 372$ year $^{-1}$ for a 1 ha farm) with monsoon rice, wheat, and mung bean crops, respectively, compared to farmers practicing CT + CP [32]. Based on the above yield increases and cost savings, we estimated that the annual potential gain from $2.5 \%$ adoption of $\mathrm{CA}$ and mechanized planting in Bangladesh (this is about the current level of CA adoption across Asia) is US\$20 million (base year 2013-2014) from the additional 23,500 $t$ of aman rice, 43,000 $t$ of boro rice, $2000 \mathrm{t}$ of wheat and $5000 \mathrm{t}$ of maize grain yield plus the value of cost savings to farmers. Additional value would be created by LSPs, manufacturers and others in the value chain (mechanics, dealers, and traders). Based on the potential yield increases and costs savings to farmers, adoption of CA and the VMP planting services by only $2.5 \%$ of all farmers in Bangladesh would directly generate an additional US\$21-38 million per year [30].

In 2017, a study was undertaken to assess adoption levels and impacts on farm businesses [28]. In Durgapur Upazilla of Rajshahi district, where a concentration of effort on VMP promotion and extension of CA has occurred in the last fie years, the adoption of CA in 2016-2017 rabi season was 4.5\% of the total crop area. In three blocks, the CA planting reached $10-16 \%$ of all rabi season crops. Hence, there is evidence of early adoption by farmers where there have been programmes to build farmer awareness, confidence in the technology and the availability of the planters and LSP to offer planting services to farmers on a custom hiring basis [30]. Average benefits from the farm mechanization and CA adoption have been estimated from a study of 135 farmers as follows: $34 \%$ labor saving, $31 \%$ less seed required, $6 \%$ fertilizers saving, $32 \%$ pesticide cost saving leading to up to $10 \%$ lower production cost for lentil, mustard, maize and wheat [30]. There was a yield increase of $28 \%$ for lentil, $19 \%$ for mustard and $6 \%$ for wheat by farmers who adopted CA planting using the VMP, and profit increases by $47 \%$ for lentil, $55 \%$ for maize, $46 \%$ for mustard and $76 \%$ for wheat due to adoption of CA planting using VMP [28].

To create demand for the VMP, HC arranged widespread demonstrations of VMP operation and on-farm demonstration of crop performances by LSP for establishing wheat, onion, garlic, lentil, chickpea, mung bean, jute, etc. in study areas. For initial demand creation from new LSPs, the Conservation Agriculture project provided 50\% and 25\% price support for VMP in 2015 and 2016, respectively, but none in 2017. The Conservation Agriculture project activities created confidence by farmers, LSPs, and involved stakeholders (e.g., DAE, Barind Multipurpose Development Authority, National Bank Ltd., etc.) in VMP adoption and commercialization. Working with multi-stakeholders appears to be critically important for commercialization of this new planting machinery. The LSPs and farmers were cautious to invest money for new farm implements based on previous experiences after purchasing implements. Involvement of universities (e.g., Bangladesh Agricultural University and Murdoch University), extension agencies (e.g., DAE) and coordination through Conservation Agriculture project has built the trust among the LSPs and farmers to buy and adopt the VMP.

Based on feedback from farmers' on their requirements, ongoing modification of the VMP since 2015 has significantly reduced the market price and weight of the planter and improved weight balancing, while maintaining assurance of high-quality production. Seed meters now supplied with the VMP regulate the seed rate without field calibration. In addition, significant improvement was made on the shank of furrow openers to increase the strength, while the seed-boot and fertilizer-orifice of the furrow opener were modified to minimize seed and fertilizer contact. This improvement has strengthened confidence of LSPs and farmers in the use and performance of the VMP.

\subsection{A Roadmap for CA in the EGP}

The research and development to date describes a feasible CA practice for rice-based cropping systems in Bangladesh. However, to advance the development and adoption of CA in the EGP, we make the following recommendations:

- Governments adopt a CA policy for implementation by their agricultural extension, research and university sectors. Through respective Departments of Agricultural Extension, Governments 
should develop mass promotional activities including publicity and awareness building on CA. Laws, regulations and policies need to be reviewed to identify and amend those that hamper the profitable adoption of CA by farmers.

- Governments engage with the private sector and farmers' organisations to establish Centres for Conservation Agriculture Research and Development to represent, coordinate and guide the CA programmes of research, development and extension (R, D \& E) agencies, agricultural universities and research funding agencies. Governments and other fund providers and investors should allocate funding and work with the Centres to conduct R, D \& E on CA, to adapt it to the conditions and requirements of EGP agriculture.

- Governments and the private sector work with and strengthen CA farmers' associations to promote adoption and local adaptation of CA. Governments may need to remove bottlenecks for profitable engagement by the private sector in promoting CA.

- Protagonists for CA work with finance institutions to establish accessible, interest-free or low interest finance for CA-related machinery manufacturers, LSPs, and users and to apply incentives to LSP and farmers to take up CA practices.

For research, extension and education in the EGP on CA, we recommend the priorities are to:

- Set up and maintain long term CA experiments on key soils and agro-ecological regions to assess system productivity, improvement in soil properties over time, and identify emerging trends that affect weed, pest and disease control. In addition, there should be support for farmer-managed fields where continuous CA practice has occurred for three years or more. Targeting the early adopters of CA to assess the benefits accrued by farmers after 3-5 years is therefore a priority for future research.

- Continue to improve non-puddled rice establishment, including defining the domain of rice production in the EGP where it is best suited.

- Continue to improve ZT/SP seed drills for direct seeding of rice and reliable establishment of other crops and weed control in different field types, hydrological regimes and seasons with the aim of defining the domains where forms of CA technology are reliable for farmers to adopt.

- Where adoption occurs over a significant proportion of the landscape, undertake landscape-scale water balance studies to define the real effects of CA practice on groundwater levels and recharge rates.

- National programmes of on-farm adaptive experiments to develop improved local and regional variations on best practice for CA. In particular there is a need for recommendations on row spacing, seed rate, seedling depth, etc for CA planting of the major crops involving SP or ZT and suitable levels of crop residue retention.

- Determine fertiliser management requirements for crops under CA management.

- Develop and promote to farmers integrated weed management approaches to reduce reliance on herbicides for weed control and minimise the development of herbicide resistance in weed species.

- Routine screening of cultivars of major crops for vigour and yield in CA planting (SP and retained crop residues). In addition, for the major crops grown under $C A$, identify key traits required for CA planting and develop screening programmes to select better-adapted cultivars. Routine screening of new cultivars of major crops (rice, wheat, maize, jute, mung bean, lentil, mustard, and sunflower) needs to be instituted to identify cultivar variations in phytotoxicity and residual effects by herbicides. Since herbicides are rapidly becoming the weed control practice of choice by farmers, this recommendation is not specific to $\mathrm{CA}$, but applies to conventional tillage as well. There may well be differences in phytotoxicity though between CA with minimum soil disturbance and residue retention and conventional tillage.

- Develop second generation planters that are tested by LSPs to identify faults and limitations for crop establishment performance under more diverse soil and climatic conditions. Pilot studies 
should also begin on four-wheel tractor niches for CA in the EGP. This will involve initial studies on best bet planters for 20-30 and 40-60 horsepower tractors.

\section{Summary and Conclusions}

Research and development in Bangladesh have developed effective CA practices for smallholder farms in the EGP using minimum soil disturbing implements mounted on 2WTs. The key outcomes are new knowledge developed on: (i) effective strip planting using the VMP [4-6]; (ii) planting machinery development and performance testing in the small fields using 2WTs [4,9]; (iii) agronomy for mechanised seeding with minimum soil disturbance and residue retention [5,6]; (iv) weed dynamics and weed management under CA [11-16,33]; (v) crop rotation effects on soils and weeds [33,34]; (vi) mechanised transplanting of NPT rice [24,25]; (vii) soil improvement under CA [17-22]; (viii) decreased greenhouse gas emissions under CA [23]; (ix) increased profit from CA-based SP + NPT rice in farmers' fields [8]; (x) water balance [27], which showed that wheat under CA (SP and increased residue retained) required 11-33\% less irrigation water than the convention practices; and (xi) commercialisation models for sales of planters to LSP [31]. Based on the evidence presented, there should now be sufficient confidence for more widespread demonstrations across different agro-ecosystems in the EIP and for programmes to engage the private sector and farmers in adoption and out-scaling of CA for smallholder rice-based crop production in the EGP.

Author Contributions: R.W.B. helped with design of field evaluation trials, data analysis, and led the manuscript writing. M.E.H. led the design and fabrication of planters, and contributed to research, data collection and manuscript preparation. M.J. supervised soil research and one of the long-term experiments reviewed. M.M.R. supervised research on weed control. M.B. supervised weed seed bank research. M.A.M.M. designed, led and wrote up the surveys of on-farm profitability of CA and the LSP business models. M.A.I. set up two long-term experiments on $\mathrm{CA}$ as part of his $\mathrm{PhD}$ studies. M.A.H. conducted $\mathrm{PhD}$ research on mechanized transplanting of non-puddled rice. N.S. conducted PhD research and set up a long-term experiment on CA. T.Z. conducted $\mathrm{PhD}$ research on weed control for CA. M.M.H. conducted PhD research on weed control and CA effects on weed seedbanks. M.K.A. conducted PhD studies on greenhouse gas emissions and life cycle analysis of the CA practices. M.N.H.M. conducted PhD studies on water balance under CA.

Funding: This research was funded by the Australian Centre for International Agricultural Research (ACIAR: Project LWR/2012/080).

Acknowledgments: The authors gratefully acknowledge all professors, researchers, and students who were involved in this project. The authors also acknowledge the LSPs who provided VMP and VSSD contract planting services and helped with data collection from farmers' fields.

Conflicts of Interest: The authors declare no conflict of interest.

\section{References}

1. Bangladesh Population (LIVE). Available online: www.worldometers.info/world-population/bangladeshpopulation/ (accessed on 20 October 2018).

2. Bangladesh Bureau of Statistics. Statistical Yearbook of Bangladesh-2013; Bangladesh Bureau of Statistics, Ministry of Planning, Government of the People's Republic of Bangladesh: Dhaka, Bangladesh, 2011.

3. Johansen, C.J.; Haque, M.E.; Bell, R.W.; Thierfelder, C.; Esdaile, R.J. Conservation agriculture for small holder rainfed farming: Opportunities and constraints of new mechanized seeding systems. Field Crop. Res. 2012, 132, 18-32. [CrossRef]

4. Haque, M.E.; Bell, R.W.; Islam, A.K.M.S.; Sayre, K.D.; Hossain, M.M. An innovative Versatile Multi-crop Planter for crop establishment using two-wheel tractors. Agric. Mech. Asia Afr. Lat. Am. 2017, 48, $33-37$.

5. Bell, R.W.; Haque, M.E.; Johansen, C.; Vance, W.; Kabir, M.E.; Musa, M.A.; Mia, M.N.N.; Neogi, M.G.; Islam, M.A. Mechanised minimum tillage establishment and yield of diverse crops in paddy fields using a two-wheel tractor-mounted planter suitable for smallholder cropping. Exp. Agric. 2017, 54, 755-773. [CrossRef]

6. Vance, W.H.; Bell, R.W.; Johansen, C.J.; Haque, M.E.; Musa, M.A.; Shahidullah, A.K.M.; Mia, N.N. Optimum time of sowing for rainfed winter chickpea with one-pass mechanised row-sowing: An example for small-holder farms in north-west Bangladesh. Crop Pasture Sci. 2014, 65, 602-613. [CrossRef] 
7. Bangladesh Bureau of Statistics. Statistical Pocketbook of Bangladesh-2013; Bangladesh Bureau of Statistics, Ministry of Planning, Government of the People's Republic of Bangladesh: Dhaka, Bangladesh, 2013.

8. Haque, M.E.; Bell, R.W.; Islam, M.A.; Rahman, M.A. Minimum tillage unpuddled transplanting: An alternative crop establishment strategy for rice in conservation agriculture cropping systems. Field Crop. Res. 2016, 185, 31-39. [CrossRef]

9. Haque, M.E.; Bell, R.W.; Kassam, A.; Mia, M.N.N. Versatile Strip Seed Drill: A 2-wheel tractor-based option for smallholders to implement Conservation Agriculture in Asia and Africa. Environments 2016, 3, 1. [CrossRef]

10. Haque, M.E.; Bell, R.W. Is conservation agriculture increasing herbicide uses? A Bangladesh case. In Proceedings of the 7th World Congress of Conservation Agriculture, Rosario, Argentina, 1-4 August 2017; Bartz, M., Llanillo, R.F., Ralisch, R., Eds.; Murdoch University: Perth, Australia, 2017; p. 204.

11. Zahan, T.; Rahman, M.M.; Begum, M.; Bell, R.W.; Khan, A.S.M.M.R. Broadleaved weed management in wheat with post-emergence herbicides under strip tillage system. In Proceedings of the 2nd Conference on Conservation Agriculture for Smallholders (CASH-II), Mymensingh, Bangladesh, 14-16 February 2017; Haque, M.E., Bell, R.W., Vance, W.H., Eds.; Murdoch University: Perth, Australia, 2017; pp. 123-125.

12. Zahan, T.; Rahman, M.M.; Hashem, A. Growth and yield response of transplanted aman rice varieties to herbicides in strip tilled unpuddled soil. In Proceedings of the 2nd Conference on Conservation Agriculture for Smallholders (CASH-II), Mymensingh, Bangladesh, 14-16 February 2017; Haque, M.E., Bell, R.W., Vance, W.H., Eds.; Murdoch University: Perth, Australia, 2017; pp. 48-49.

13. Hossain, M.M.; Begum, M.; Rahman, M.M.; Hashem, A.; Bell, R.W.; Haque, M.E. Weed seed bank dynamics in long term trials of conservation agriculture. In Proceedings of the 2nd Conference on Conservation Agriculture for Smallholders (CASH-II), Mymensingh, Bangladesh, 14-16 February 2017; Haque, M.E., Bell, R.W., Wendy, W.H., Eds.; Murdoch University: Perth, Australia, 2017; pp. 41-43.

14. Rahman, M.M.; Zahan, T. Tolerance of rice varieties to higher rates of two post-emergence herbicides under strip tilled non-puddled transplanted establishment. In Proceedings of the 2nd Conference on Conservation Agriculture for Smallholders (CASH-II), Mymensingh, Bangladesh, 14-16 February 2017; Haque, M.E., Bell, R.W., Vance, W.H., Eds.; Murdoch University: Perth, Australia, 2017; pp. 44-45.

15. Zahan, T.; Rahman, M.M.; Begum, M. Residual effect of herbicides applied in unpuddled transplanted aman rice on the succeeding crops assessed by bioassay technique. Bangladesh Agron. J. 2016, 19, 95-103. [CrossRef]

16. Zahan, T.; Hashem, A.; Rahman, M.M.; Bell, R.W.; Begum, M. Efficacy of herbicides in non-puddled transplanted rice under conservation agriculture systems and their effect on establishment of the succeeding crops. Acta Sci. Malays. 2018, 2, 17-25. [CrossRef]

17. Islam, M.A. Conservation Agriculture: Its Effects on Crop and Soil in Rice-Based Cropping Systems in Bangladesh. Ph.D. Thesis, School of Veterinary and Life Sciences, Murdoch University, Murdoch, Australia, 2017; p. 365.

18. Alam, M.K.; Bell, R.W.; Haque, M.E.; Kader, M.A. Minimum soil disturbance and increased residue retention increase soil carbon in rice-based cropping systems on the Eastern Gangetic Plain. Soil Tillage Res. 2018, 183, 28-41. [CrossRef]

19. Alam, M.K. Bangladesh Agricultural Research Institute: Gazipur, Bangladesh, 2018. Unpublished work.

20. Salahin, N.; Jahiruddin, M.; Islam, M.R.; Bell, R.W.; Haque, M.E.; Alam, M.K. Changes in soil organic matter, plant nutrients and system productivity under conservation agricultural practices in the rice-jute cropping system. In Proceedings of the 2nd Conference on Conservation Agriculture for Smallholders (CASH-II), Mymensingh, Bangladesh, 14-16 February 2017; Haque, M.E., Bell, R.W., Wendy, W.H., Eds.; Murdoch University: Perth, Australia, 2017; pp. 117-119.

21. Salahin, N. Influence of Minimum Tillage and Crop Residue Retention on Soil Organic Matter, Nutrient Content and Crop Productivity in the Rice-Jute System. Ph.D. Thesis, Department of Soil Science, Bangladesh Agricultural University, Mymensingh, Bangladesh, 2017; p. 246.

22. Jahiruddin, M.; Hossain, R.; Paul, T.; Islam, M.R.; Kader, M.A.; Haque, M.E.; Bell, R.W. Strip tillage with residue retention increases soil organic carbon, nitrogen requirement and system productivity of a rice-wheat-mungbean cropping system. In Proceedings of the 2nd Conference on Conservation Agriculture for Smallholders (CASH-II), Mymensingh, Bangladesh, 14-16 February 2017; Haque, M.E., Bell, R.W., Wendy, W.H., Eds.; Murdoch University: Perth, Australia, 2017; pp. 12-13. 
23. Alam, M.K.; Biswas, W.K.; Bell, R.W. Greenhouse gas implications of novel and conventional rice production technologies in the Eastern-Gangetic plains. J. Clean. Prod. 2016, 112, 3977-3987. [CrossRef]

24. Haque, M.E.; Bell, R.W.; Islam, M.A.; Alam, M.K.; Mahmud, M.N.H.; Jahiruddin, M. Long-term impact of smallholders' Conservation Agriculture in rainfed and irrigated systems. In Proceedings of the 2nd African Congress of Conservation Agriculture, Johannesburg, South Africa, 9-12 October 2018; African Tillage Network: Nairobi, Kenya, 2018; pp. 197-200.

25. Hossen, M.A.; Hossain, M.M.; Haque, M.E.; Bell, R.W. Transplanting into non-puddled soils with a small-scale mechanical transplanter reduced fuel, labour and irrigation water requirements for rice (Oryza sativa L.) establishment and increased yield. Field Crops Research. Field Crop. Res. 2018, 225, 141-151. [CrossRef]

26. Hossen, M.A. Development of Rice Transplanter for Unpuddled Condition. Ph.D. Thesis, Department of Farm Power and Engineering, Bangladesh Agricultural University, Mymensingh, Bangladesh, 2017; p. 312.

27. Mahmud, M.N.H.; Bell, R.W.; Vance, W. Strip planting increases yield and water productivity of wheat (Triticum aestivum) in Northwest Bangladesh. In Proceedings of the International Conference on Agri Biotech and Environmental Engineering, San Antonio, TX, USA, 11-12 September 2017; p. 32.

28. Miah, M.A.M.; Rashid, M.A.; Haque, M.E.; Bell, R.W. Adoption Impacts of Conservation Agriculture Technologies at Farm Level in Bangladesh; Agricultural Economics Division, Bangladesh Agricultural Research Institute and Murdoch University: Murdoch, Australia, 2017; p. 47.

29. Pieri, C.; Evers, G.; Landers, J.; O'Connell, P.; Terry, E. No-Till Farming for Sustainable Rural Development; Agriculture and Rural Development Working Paper; FAO: Rome, Italy, 2002.

30. Haque, M.E.; Bell, R.W.; Jahiruddin, M.; Hossain, M.M.; Rahman, M.M.; Begum, M.; Hossen, M.A.; Salahin, N.; Zahan, T.; Hossain, M.M.; et al. Manual for Smallholders' Conservation Agriculture in Rice-based Systems; Murdoch University: Perth, Australia, 2018; p. 108.

31. Haque, M.E.; Bell, R.W.; Menon, R.K.; Hoque, M.M.; Hossain, M.M.; Rahman, M.A.; Hossain, M.I.; Chowdhury, A.H.; Mortuza, M.A.H. Commercialization approach for Versatile Multi-Crop Planter: Lessons learnt. In Proceedings of the 2nd Conference on Conservation Agriculture for Smallholders (CASH-II), Mymensingh, Bangladesh, 14-16 February 2017; Haque, M.E., Bell, R.W., Vance, W.H., Eds.; Murdoch University: Perth, Australia, 2017; pp. 65-68.

32. Haque, M.E.; Bell, R.W.; Vance, W.; Mia, N.N. Designing Intensive Crop Sequences for Conservation Agriculture Using Mechanized Planters on Two-Wheel Tractors. In Proceedings of the 4th International Symposium for Farming Systems Design, Lanzhou, China, 19-22 August 2013; Chen, F., Gao, W., Eds.; Gansu Science and Technology Press: Lanzhou, China, 2013; pp. 251-252.

33. Hossain, M.M.; Begum, M.; Hashem, A.; Rahman, M.M.; Bell, R.W.; Haque, M.E. Yield response of mustard as influenced by weed management practice under conservation agriculture system. Bangladesh J. Weed Sci. 2014, 4, 87-92.

34. Hossain, M.M.; Begum, M.; Hashem, A.; Rahman, M.M.; Bell, R.W.; Haque, M.E. Yield response of transplanted aman rice to weed management practice under conservation agriculture system. In Proceedings of the 25th Conference of Asian-Pacific Weed Science Society, Hyderabad, India, 13-16 October 2015; Indian Society of Weed Science: Jabalpur, India, 2015; Volume 3, p. 594.

(C) 2018 by the authors. Licensee MDPI, Basel, Switzerland. This article is an open access article distributed under the terms and conditions of the Creative Commons Attribution (CC BY) license (http://creativecommons.org/licenses/by/4.0/). 